Gut, 1986, 27, 444-449

Case reports

\title{
Dextropropoxyphene induced hepatotoxicity mimicking biliary tract disease
}

\author{
M F BASSENDINE, $\mathrm{K}$ W WOODHOUSE, M BENNETT, AND O F W JAMES \\ From the Departments of Medicine and Pathology, Freeman Hospital and the Department of Medicine \\ (Geriatrics), Royal Victoria Infirmary, Newcastle upon Tyne.
}

SUMMARY Three patients are described with recurrent jaundice, upper abdominal pain and rigors attributable to dextropropoxyphene hepatotoxicity. The diagnosis was established in each patient by rechallenge; post challenge hepatic histology is reported in two. Twelve previous patients with probable dextropropoxyphene hepatic toxicity have been described and are reviewed. In 10 of the 15 patients, a clinical diagnosis of gall stone disease was made. Liver function tests are usually hepatitic shortly after challenge, but more cholestatic after a few days. No fatalities have been described, but as dextropropoxyphene is widely available in many different analgesic preparations possible toxicity should be considered in patients with relapsing jaundice mimicking biliary disease, in whom gall stones have been excluded.

Dextropropoxyphene is widely used as an analgesic both alone and in combination with other drugs. Although several reports have suggested that it may rarely cause liver damage, ${ }^{1-9}$ a causal relationship has only been firmly established by rechallenge in a total of six patients and in only two was hepatic histology available after the rechallenge. We report three patients in whom dextropropoxyphene was responsible for hepatotoxicity.

\section{Case histories}

PATIENT 1

A 52 year old woman had two episodes of unexplained jaundice in 1981 and 1982. On each occasion jaundice lasted about two weeks and was accompanied by pruritus, nausea, and intolerance of fatty foods. No investigations were carried out. The patient had osteoarthritis of the right knee for which she took various analgesics, usually Benorylate (an aspirin-paracetamol ester). She had a known allergy to penicillin. The patient was admitted to hospital with a history of sudden onset of jaundice for a third time three weeks previously, the jaundice had been preceded by epigastric pain for a few hours and was

Address for correspondence: Dr O F W James, Medical Unit No 1, Freeman Hospital, Newcastle upon Tyne. NE7 7DN.

Received for publication 2 August 1985. accompanied by dark urine, pale stools, malaise, and pruritus. Investigations: bilirubin $76 \mu \mathrm{mol} / \mathrm{l}$, alkaline phosphatase 121 IU/l (normal<92), aspartate aminotransferase 169 IU/l (normal<37). Autoantibody screen negative. HBsAg negative, anti HBs negative, anti $\mathrm{HBc}$ negative, HAV IgM negative. Abdominal ultrasound - no abnormality of intrahepatic or extrahepatic biliary tree but poor sonar subject. ERCP: normal biliary tree, normal gall bladder. Liver biopsy showed focal lobular mononuclear cell inflammatory infiltrate accompanied by centrilobular cholestasis. An occasional acidophil body and double nucleated hepatocytes were also seen. Portal tracts showed a focal mononuclear cell inflammatory infiltrate. Liver function tests settled to normal after a further four weeks (total abnormality of liver function tests seven weeks). On further inquiry from the patient's general practitioner it transpired that she had been given a prescription for Distalgesic (paracetamol plus dextropropoxyphene) in the month before the latest episode of jaundice although the patient had only remembered taking Benorylate. Accordingly, the patient was readmitted to hospital and given a 'challenge' of $32.5 \mathrm{mg}$ dextropropoxyphene by mouth. After 10 hours she experienced cramplike abdominal pain in the right upper quadrant accompanied by nausea and fever. Liver function tests are shown in Figure 1. Liver biopsy was carried out six days after challenge. This 

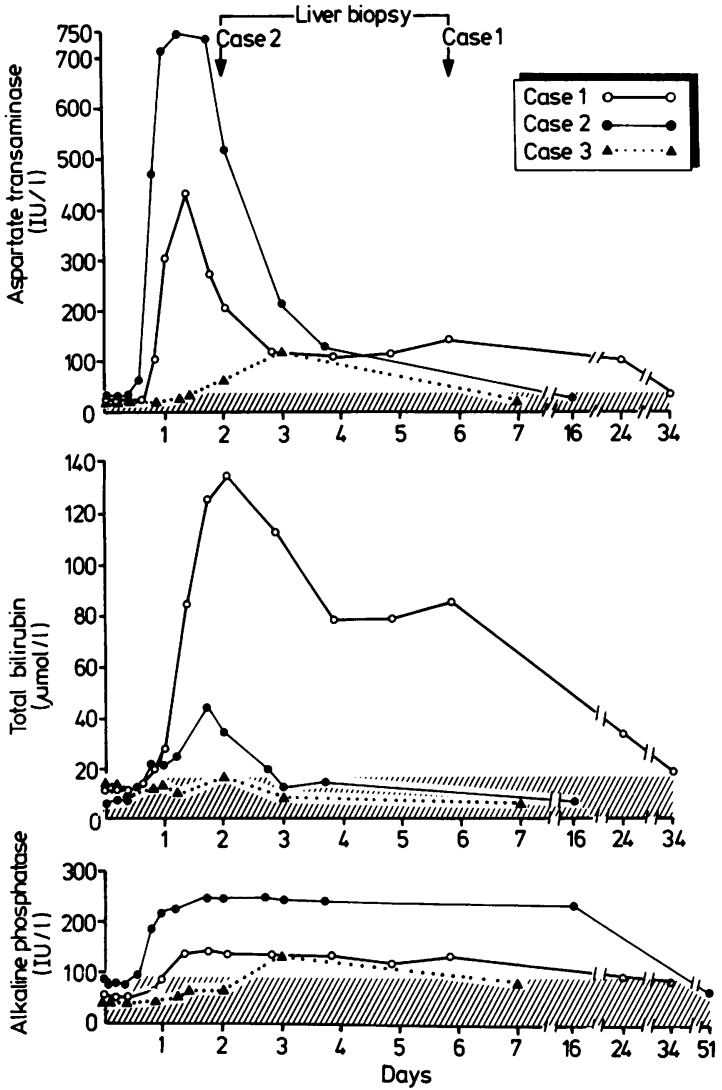

Fig. 1 (Case 1) Liver function tests after oral challenge with $32.5 \mathrm{mg}$ dextropropoxyphene at time 0 in cases 1,2 and 3 .

again showed centrilobular cholestasis. Oedematous portal tracts contained numerous eosinophils and a few mononuclear cells. The eosinophils were not infrequently situated around bile ducts (Fig. 2) and occasionally were seen passing through the basement membrane. Ultrastructurally dilatation of canaliculi with loss of microvilli was seen, most marked in the centrilobular areas. The biliary concretions had a granular appearance and within the cytosol, mitochondria showed elongation and curling of the cristae (Fig. 3). After the onset of jaundice she had pruritus and malaise, liver function tests were still abnormal after 24 days (bilirubin 35, alkaline phosphatase 96, AST 102) but had returned to normal after five weeks.

\section{PATIENT 2}

A 65 year old woman with a long history of facial pain reported three episodes of jaundice in the three months before hospital referral. On each occasion she developed upper abdominal pain, fever, and jaundice starting about 12 hours after taking Distalgesic tablets (she normally took paracetamol alone). On each occasion jaundice lasted a few days and was accompanied by dark urine and pale stools. The following investigations had been carried out: bilirubin $40 \mathrm{IU} / \mathrm{l}$, AST 270, alkaline phosphatase 22 KAU $(\mathrm{N}<13)$. Abdominal ultrasound showed normal intra- and extrahepatic biliary tree. Oral cholecystogram normal, intravenous cholangiogram normal. In addition autoantibody screen, HBV markers and HAV IgM were all negative. She was admitted to hospital and given an oral challenge dose of $32.5 \mathrm{mg}$ dextropropoxyphene. After 10 hours she developed cramping upper abdominal pain, fever, and nausea. Liver function tests are shown in Figure 1. Liver biopsy was carried out 48 hours after the challenge. This showed normal hepatic architecture, but hypertrophied Küpffer cells were seen throughout the lobules. An inflammatory infiltrate of eosinophils and lymphocytes was present in most portal tracts (Fig. 4). No polymorphs, significant oedema or bile ductule proliferation were seen. Liver function tests had returned to normal after 16 days except for a raised alkaline phosphatase of 138 . She remained quite well with normal liver function tests after seven weeks.

\section{PATIENT 3}

A 22 year old nurse was admitted to hospital with sciatica. She was treated with pelvic traction and analgesics (paracetamol, pentazocine, codeine phosphate). She was subsequently given aspirin and Distalgesic. She then developed severe epigastric pain, nausea, and vomiting followed by rigors and sweating. A few days later she became mildly icteric with pruritus and pale stools. Her sciatica had eased so all analgesics were stopped. Investigations were as follows: bilirubin 46, AST 149, alkaline phosphatase 290, amylase $125 \mathrm{IU} / \mathrm{l}$ (normal<300). HBV markers, HAV IgM, autoantibodies, all negative. Ultrasound showed no abnormality in the biliary tree and gall bladder. Liver function tests returned to normal after 10 days except for a raised alkaline phosphatase of 138 . Three months later liver function tests were normal, and she was readmitted and given a 'challenge' with dextropropoxyphene $32.5 \mathrm{mg}$ by mouth. Twenty four hours later she became nauseated and vomited several times and developed upper abdominal pain which lasted 12 hours. Liver function tests are shown in Figure 1. Liver biopsy was refused.

\section{Discussion}

Dextropropoxyphene has been widely used as an 

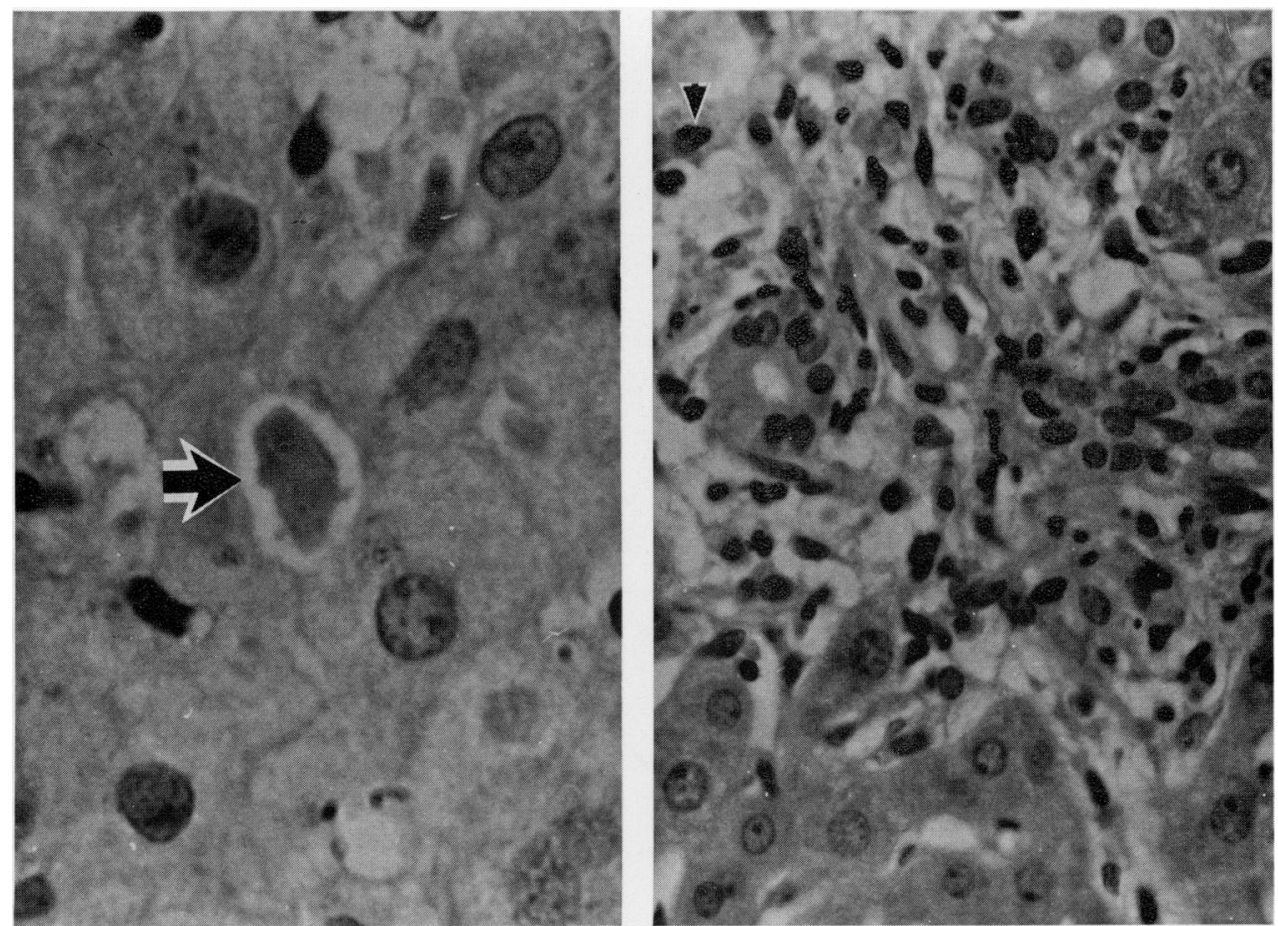

Fig. 2 (Case 1) Near the central veins, cholestasis was indicated by bile thrombi (arrow) (original magnification $\times 1280)$. Oedematous portal tracts contain both eosinophils and lymphocytes (original magnification $\times 512$ ).



Fig. 3 (Case 2) Electromicrograph shows dilated bile canaliculae, containing granular material. Adjacent hepatocyte mitochondria show curling of the cristae (original magnification $\times 6000)$. 


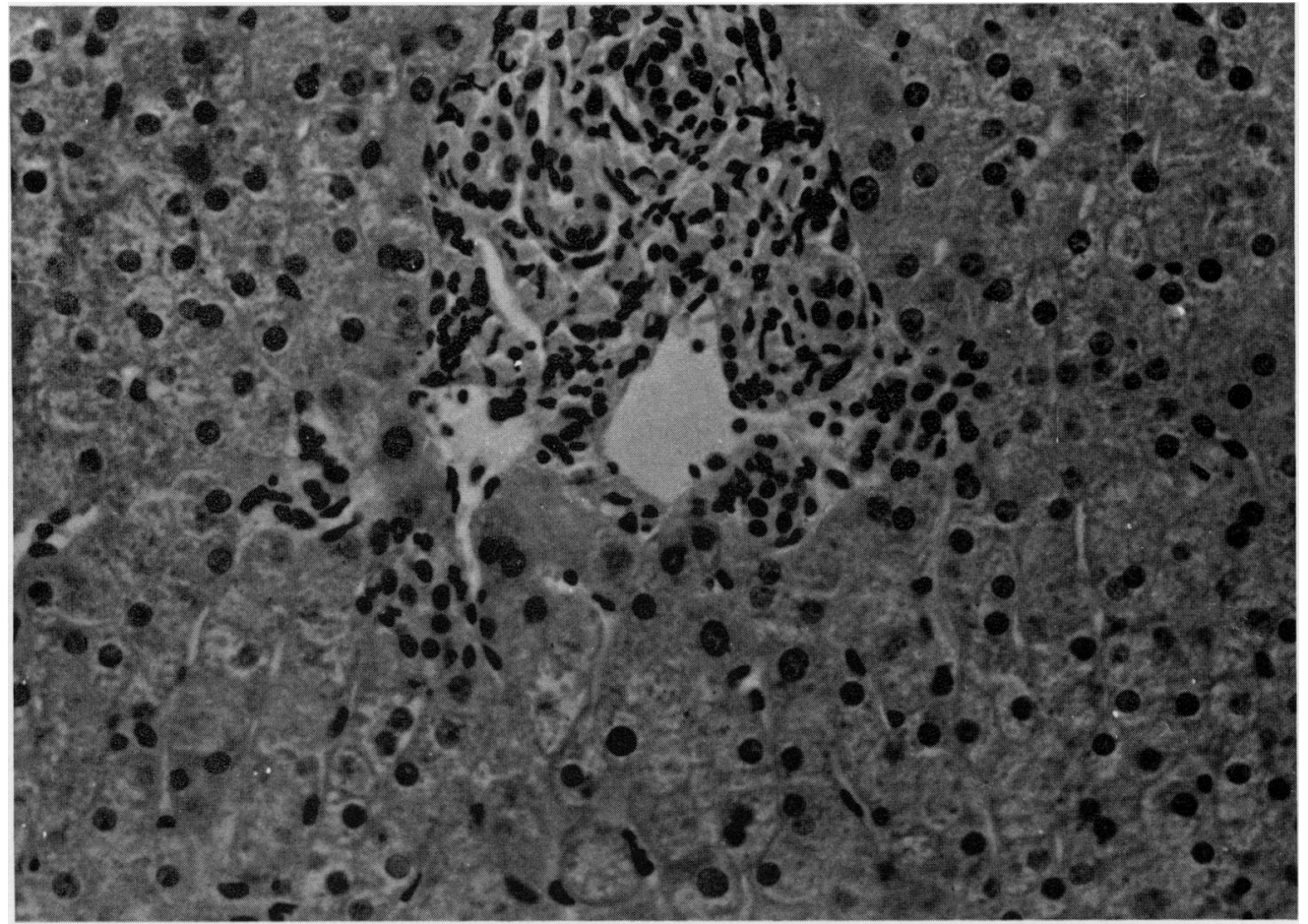

Fig. 4 Portal tract shows an increase in lymphocytes with an occasional eosinophil. Küpffer cells are hypertrophied within the adjacent sinusoids (original magnification $\times 320$ ).

Table Details of patients

\begin{tabular}{|c|c|c|c|c|c|}
\hline Reference & Age & Sex & Clinical features & Challenge & Histology \\
\hline $\begin{array}{l}\text { 1. Klcin and Magida } \\
1971\end{array}$ & 39 & M & Fever, anorexia, malaise & $\begin{array}{l}\text { Mixed/hepatitic } \\
\text { LFTs }\end{array}$ & $\begin{array}{l}\text { Intrahepatic cholestasis periportal } \\
\text { infiltrate, round cclls, } \\
\text { polymorphs and eosinophils }\end{array}$ \\
\hline $\begin{array}{l}\text { 2. Daikos and Kosmidis } \\
1975\end{array}$ & 47 & $\mathbf{M}$ & $\begin{array}{l}\text { Upper abdominal pain then dark } \\
\text { urine, pale stools }\end{array}$ & Mixed LFTs & - \\
\hline \multirow[t]{2}{*}{ 3. Lee and Rees 1977} & 56 & $\mathbf{M}$ & $\begin{array}{l}\text { Relapsing jaundice, upper } \\
\text { abdominal pain followed by jaundice }\end{array}$ & Mixed LFTs & $\begin{array}{l}\text { Mild portal fibrosis (before } \\
\text { challenge) }\end{array}$ \\
\hline & 66 & $\mathrm{~F}$ & $\begin{array}{l}\text { Malaise and tiredness found to } \\
\text { have abnormal LFTs }\end{array}$ & $\begin{array}{l}\text { Pyrexia, mildly } \\
\text { abnormal LFTs }\end{array}$ & - \\
\hline \multirow[t]{3}{*}{ 4. Ford et al. 1977} & 54 & $\mathrm{~F}$ & $\begin{array}{l}\text { Rigors, jaundice, pruritus } \\
\Delta \text { gall stones-laparotomy }\end{array}$ & 一 & $\begin{array}{l}\text { Intrahepatic cholestasis, portal } \\
\text { tracts infiltrated with plasma } \\
\text { cells, lymphocytes, cosinophils }\end{array}$ \\
\hline & 32 & $\mathrm{~F}$ & $\begin{array}{l}\text { Recurrent epigastric pain, } \\
\text { nausea, dark urine, pale stools }\end{array}$ & - & - \\
\hline & 45 & $\mathrm{~F}$ & $\begin{array}{l}\text { Pruritus, pale stools and dark } \\
\text { urine then jaundice. } \Delta \text { gall } \\
\text { stones-laparotomy }\end{array}$ & - & Intrahepatic cholestasis \\
\hline $\begin{array}{l}\text { 5. Pramming and } \\
\text { Peterson } 1978\end{array}$ & 62 & $\mathrm{~F}$ & Abdominal pain? gall stones & Mixed LFTs & Cholestasis, intrahepatic oedema \\
\hline $\begin{array}{l}\text { 6. Van Brenkilen and } \\
\text { Schrijver } 1978\end{array}$ & 72 & $\mathrm{~F}$ & $\begin{array}{l}\text { Fever, abdominal pain, } \\
\text { jaundice-? gall stones }\end{array}$ & Hepatitic LFTs & - \\
\hline $\begin{array}{l}\text { 7. Adverse Drug } \\
\text { Committee Australia } \\
1979\end{array}$ & 56 & $\mathrm{~F}$ & $\begin{array}{l}\text { Nausea and relapsing jaundice } \\
\text { mixed LFTs }\end{array}$ & - & - \\
\hline 8. Lindholm 1979 & 77 & $\mathrm{~F}$ & $\begin{array}{l}\text { Fever and jaundice } \\
\text { Cholestatic LFTs }\end{array}$ & - & - \\
\hline $\begin{array}{l}\text { 9. Kerst and Strik } \\
1979\end{array}$ & 46 & $\mathbf{F}$ & Recurrent cholestasis & - & Intrahepatic cholestasis \\
\hline
\end{tabular}

LFTs=liver function tests. 
analgesic both alone and, more commonly, in combination with other drugs. Indeed Distalgesic is the second most commonly prescribed analgesic in the United Kingdom. ${ }^{10}$ Dextropropoxyphene is present in many preparations (currently at least eight are listed in the British National Formulary) and has been in use for more than 15 years. Hepatic toxicity reliably attributable to dextropropoxyphene is rare - only 12 cases have hitherto been reported in the literature. ${ }^{1-9}$ The first report was in 1971. Liver biopsies have been carried out in only six patients and rechallenge with dextropropoxyphene alone has been carried out in only five patients (in two of whom a liver biopsy was also available). The previously reported cases are summarised in the Table. The present three patients are important for a number of reasons.

\section{CLINICAL HISTORY}

In each case the history was of epigastric pain, nausea and vomiting and the symptoms were accompanied by fever and/or rigors followed by jaundice, pale stools and dark urine. In all three patients a clinical diagnosis of biliary tract disease was made. The symptoms described have been a feature of over half of the previously documented cases and this was sufficiently convincing to lead to laparotomy for cholecystectomy in two. In all three of our patients different analgesics had been taken over a variable period thus the incrimination of dextropropoxyphene was difficult and only proven by rechallenge.

\section{RECHALLENGE}

In each instance symptoms of severe malaise and abdominal pain began within 24 hours after rechallenge with a low dose of dextropropoxyphene hydrochloride $(32.5 \mathrm{mg})$ - equivalent to the contents of only 1 tablet of the majority of compound preparations or half a tablet of the non compound preparation. In patients 1 and 2 liver function tests became abnormal within 24 hours and were predominantly hepatitic initially. This was followed by a more prolonged cholestatic phase; three weeks postchallenge patient 1 still had a raised serum bilirubin and patient 2 a raised alkaline phosphatase. The marked abnormality of liver function tests after challenge ultimately returned completely to normal. Each patient felt unwell for about two weeks. In patient 3 where rechallenge followed only one dose liver function tests were slower to become abnormal, were less deranged and returned to normal more quickly. This patient's period of ill health was short.

\section{LIVER HISTOLOGY}

In both of the present patients where postchallenge biopsies are available the portal tract infiltrate of eosinophils and lymphocytes is suggestive of a drug hypersensitivity reaction. Although not very fully documented only one previous histological report has shown a portal infiltrate of plasma cells, lymphocytes and eosinophils. Other previous liver biopsies have only described cholestasis. In patient 1 where liver biopsy was carried out six days postchallenge during the more cholestatic phase of the 'illness', centrilobular cholestasis was a feature. The ultrastructural changes with biliary concretions are similar to those found in chlorpromazine jaundice.

\section{POSSIBLE MECHANISM OF HEPATOTOXICITY}

The rarity of hepatic toxicity from dextropropoxyphene, the clinical features of fever and rigors shortly after exposure, the marked hepatic toxicity after a small challenge dose and the histological features all point to the probability of a hypersensitivity or immune mechanism. In this connection it is of interest that 1 patient had a history of hypersensitivity to other drugs (penicillins). The hypersensitivity could be to dextropropoxyphene itself or to a normal or abnormal metabolite. The same dose of dextropropoxyphene in different individuals gives rise to a wide variation in plasma concentrations that result from differences in absorption and biotransformation. ${ }^{11}$ All three of our patients were women, as were nine of 12 of the previous cases. Men and women have been shown to have different propoxyphene kinetic profiles after a single dose, women exhibiting more extensive first pass biotransformation to nor-propoxyphene. ${ }^{12}$ Elimination of nor-propoxyphene may be influenced by the rate of conjugation so plasma concentrations of dextropropoxyphene and nor-propoxyphene depend on rates of absorption, metabolism predominantly $\mathrm{N}$-demethylation - and conjugation. However the 'normal' half-life of propoxyphene after a single dose is three hours and norpropoxyphene is 16.8 hours so that peak concentrations of dextropropoxyphene metabolite(s) could account for the time scale of the drug's hepatotoxicity. The mechanism of this rare hepatotoxic reaction requires further investigation.

We thank Dr R Lendrum for permission to publish details of case 3 and also Mrs A Asch who prepared the manuscript.

\section{References}

1 Klein NC, Magida MG. Propoxyphene (Darvon) hepatotoxicity. Am J Dig Dis 1971; 16: 467-9. 
2 Daikos GK, Kosmidis JC. Propoxyphene jaundice. JAMA 1975; 232: 835.

3 Lee TH, Rees PJ. Hepatotoxicity of dextropropoxyphene. Br Med J 1977; II: 296-7.

4 Ford MJ, Kellett RJ, Busuttil A, Finlayson NDC. Dextropropoxyphene and jaundice. $\mathrm{Br}$ Med J 1977; II: 674.

5 Pramming S, Petersen HO. Dextropropoxifene and liver involvement. Ugeskr Laeg 1978; 140: 2249.

6 Breukelen FJM van, Shrijver H. Icterus during treatment with D-propoxyphene (Depronal). Ned T Geneesk 1978; 122: 870-2.

7 Adverse Drug Reactions Advisory Committee. Dextropropoxyphene. Med J Aust 1979; 2: 494.
8 Lindholm L. Fever, skin and liver reactions in a patient treated with Paraflex comp. Lakartidningen 1979; 76: 2795-6.

9 Kerst AJFA, Strik HPM. Bijwerkingen van Geneesmiddelen. Ned Tidschr Geneeskd 1979; 123: 1570-2.

10 A new look at Distalgesic. [Editorial]. Drug Ther Bull 1978; 16: 71-2.

11 Verebely K, Inturrisi CE. Disposition of propoxyphene and norpropoxyphene in man after a single dose. Clin Pharmacol Ther 1974; 15: 302-9.

12 Inturnsi CE, Colburn WA, Verebey K, Dayton HE, Woody GE, O'Brien CP. Propoxyphene and norpropoxyphene kinetics after single and repeated doses of propoxyphene. Clin Pharmacol Ther 1982; 31: $157-67$. 